\title{
A Tale of Two Sisters. The Image of Eve in the Early Rabbinic Literature and its Influence on the Portrayal of Lilith in the Alphabet of Ben Sira
}

\section{Abstract:}

The purposes of this paper are (1) to outline the early Jewish traditions concerning Lilith so as to provide the backdrop for (2) the reconstruction of the main elements of her image in the Alphabet of Ben Sira [ABS] which contains the most elaborate variant of the Lilith-myth. The latter in turn will be (3) confronted with the early rabbinic traditions concerning Eve so as (4) to present the role of Lilith in unburdening Eve of her problematic past on the one hand and (5) to acknowledge the role of Eve in elevating Lilith to the position of the "prototypical" Jewish femme fatale. The conclusions are that (1) the image of Lilith in the ABS draws from the traditions arose around Eve in the early rabbinic literature; (2) the main difference lies in the fact that Lilith is portrayed as far more defined and unambiguous; (3) one of the functions of Lilith in the ABS is to promote the positive image of Eve.

Keywords: Lilith, Eve, Alphabet of Ben Sira

According to various dictionaries and encyclopedias Lilith is the ancient female goddess incorporated into the mythology of Judaism and Christianity as the first wife of Adam, who rebels against her husband and turns into a demonic seducer and child-stealer. ${ }^{1}$ This assertion needs at least two additional remarks. First, the ancient sources are rather laconic when it

\footnotetext{
1 See for instance the following entries. Matthew Bunson, "Lilith", in The Vampire Encyclopedia, Idem, (New York: Gramercy Books, 1993), p. 157. Rebecca Lesses, "Lilith", in Encyclopedia of Religion, ed. Lindsay Jones et at., $2^{\text {nd }}$ edition, vol. 8, (Detroit et al.: Thomson Gale 2005), pp. 5458-5460. For the relatively recent works reviewing the modern mythologies of Lilith see: Amelia Burstein, Lilit - ha-Feministit ha-Rishonah. Keytzad Hishpi 'u Re'ayonot Feministiim 'al ha-Qri'ah shel Sipur Lilit?, [term paper], http://goo.gl/PduaZu, accessed November 11 $1^{\text {th }}, 2015$, pp. 41-57. Barbara Black Koltuv, The Book of Lilith, (Berwick Maine: Nicolas-Hays Inc., 1986). Eli Eshed, Sippurey Lilit, http://www.yekum.org/2013/03/סיפורי-לילית-אלי-אשד/, accessed November 11 2015. Stephanie I. Spoto, The Figure of Lilith and the Feminine Demonic in Early Modern Literature, (Edinburgh: The University of Edinburgh, 2012).
} 
comes to Lilith and the elaborate variant of the myth is contained only in the medieval Alphabet of Ben Sira [ABS]. Second and more importantly, a careful reading of the ABS reveals that it heavily relies upon the earlier traditions that are only secondarily attributed to Lilith. Surprisingly and somewhat counterintuitively, significant number of these ideas seem to originate from the rabbinic legends arose around the figure of Eve, who appears to be not only "older" than Lilith but also even more "sinful". The purposes of this paper are therefore (1) to outline the early, pre-ABS Jewish traditions concerning Lilith so as to provide the backdrop for (2) the reconstruction of the main elements of her image in the ABS. The latter in turn will be (3) confronted with the early traditions concerning Eve so as (4) to present the role of Lilith in unburdening Eve of her problematic past on the one hand and (5) to acknowledge the role of Eve in elevating Lilith to the position of the "prototypical" Jewish femme fatale. ${ }^{2}$

\section{Lilith in the Early Sources}

The Heb. lilit is most probably a loan word from Akkadian where the root lil means "wind" or "breath" and, by extension, "god" or "demon". The direct object of borrowing were the words lilu (masculine) and lilitu (feminine), which denoted rather indefinite category of malevolent spirits in various collections of the apotropaic incantations, such as Maqlu, Shurpu or Utukku Lemnutu. ${ }^{4}$ The Hebrew Bible [HB], being the oldest Hebrew text speaking about Lilith, mentions her directly only once in the description of the desolated ruins of Edom

2 I would like to express my gratitude to both of my anonymous reviewers for an in-depth analysis of the initial version of this paper. Their lucid and precise remarks helped me to sharpen the arguments, reformulate the conclusions and to return Lilith her due. Still, I take full responsibility for all the remaining shortcomings.

3 Yet, already a swift look at the entries gathered in the proximity of lilu and lilitu in The Assyrian Dictionary of the Oriental Institute of the University of Chicago (vol. 9, pp. 188-191) clearly shows that there is a wide a range of words possibly related but extremely varied in regards with their meaning. Furthermore, in the Western and Central Semitic languages such as Ugaritic, Aramaic and Hebrew the same root means "night" and is occasionally anthropomorphized. See: Manfred Hutter, "Lilith", in Dictionary of Deities and Demons in the Bible, eds. Karel van der Toorn, Bob Becking, Pieter Willem van der Horst, (Leiden-Boston-Koln: Brill, 1999), [DDD], p. 520; Emile Puech, "Lel", in DDD, pp. 508-511. In sum, the etymology of "Lilith" remains obscure and even the most widely accepted hypotheses prove moderately helpful in establishing the initial meaning of the word.

4 Hutter, "Lilith", pp. 520-521. 
in Isaiah 34:3-23. There is an ongoing discussion whether the word lilit present in v. 14 initially denoted a regular nocturnal scavenger or some supernatural being and despite the original meaning of the word in Akkadian, there is a strong case for the former interpretation. ${ }^{5}$ Yet, it is the latter exposition which finds support in the earliest translations, utilizing such words as onokentauros (LXX) or lamia $(\mathrm{Vg}){ }^{6}$ Apart from this instance there are several biblical passages which are sometimes taken as containing the implicit references to Lilith. First, an apotropaic Psalm 91:5-6 acknowledges the divine protection against the "terror of the night" (Heb. pachad laylah) and although the phrase itself is ambiguous, it is juxtaposed with Deber (Eng. "plague”) and Qetev (Eng. “destruction”), in this context interpreted as malevolent demons afflicting humans. ${ }^{7}$ Second, an analogical phrase appears in Canticles 3:78, where it is said that there are sixty men armed with "his sword at his hip" (Heb. charbo 'al yerekho), ready to protect the couple of lovers against the terror in the nights (Heb. mi-pachad ba-leylot $).{ }^{8}$ Third, one can also wonder whether the figure of Delilah, the fatal lover of Samson, contributed to the later understanding of Lilith. ${ }^{9}$ Finally, Lilith as a demonic creature appears also in the Dead Sea Scrolls. In the Songs of the Sage (4Q510-511) she is listed among the angels of destruction (Heb. malakhey chebel) and bastard spirits (Heb. ruchot

5 See an excellent deconstruction of the biblical demonology by Judit Blair, who devotes a good portion of her dissertation to Lilith. Idem, De-demonising the Old Testament. An Investigation of Azazel, Lilith, Deber, Qeteb and Reshef in the Hebrew Bible, [PhD thesis], (Edinburgh: University of Edinburgh, 2009), pp. 68-103. Moshe $\mathrm{Ra}^{\prime}$ anan identifies the Heb. lilit with qa'at usually rendered as "pelican" or "owl". Idem, Qa'at ve-Qippod (Mo 'ed Qatan 25b), http://daf-yomi.com/DYItemDetails.aspx?itemId=28259, accessed November $15^{\text {th }}$, 2015.

6 In fact, the word onokentauros is applied twice in the Greek rendition of the said verse with the first instance rendering the problematic tziyyim 'et 'iyyim. It is thus unsure whether the translator understood Lilith as a kind of onocentaur, tried to annul her being in the verse or had a different manuscript at their disposal. Still, due to the presence of both onokentauroi and daimones one can have no doubts in regards with the supernatural reading of the passage in the LXX. For a lucid juxtaposition of the translations of Isaiah 34:14 see: Idit Pintel-Ginsberg, Lilit - Toldot ha-Musag u-Me'aphyeney Dmutah, [MA thesis], (Jerusalem: Hebrew University, 1981), http://hcc.haifa.ac.il/ deamon/lessons/12/lilit12.htm, accessed November 11 $1^{\text {th }}, 2015$.

7 For the inherent qualities of Psalm 91 which have contributed to its apotropaic interpretation and usage see: Andrew J. Schmutzer, "Psalm 91: Refuge, Protection and its Use in the New Testament", in The Psalms: Language for All Seasons of the Soul, eds. Andrew J. Schmutzer, David M. Howard Jr., (Chicago: Moody Publishers, 2013), especially pp. 87-88. Panagiotis Stamatopoulos, A mistranslation or a liberal rendering in Ps. 91/90:6 (LXX)?, [paper draft, no date of publication], https://www.academia.edu/4167142/_English_A_mistranslation_or_a liberal_rendering_in_Psalm_91_90_6_L XX_, accessed July $19^{\text {th }}, 2016$, p. 4.

8 Meir Malul, "Terror of the night", in DDD, pp. 851-854. For the apotropaic significance of this fragment of Canticles see: Gianni Barbiero, Song of Songs. A Close Reading, (Leiden: Brill, 2011), pp. 150-152.

9 Interestingly, these names contain implicit references to "night" (Heb. laylah) and "sun" (Heb. shemesh). 
mamzerim) who fall upon men, while the Magical Booklet (4Q560) and Apocryphal Psalms (11Q11) furnish apotropaic spells directed against Lilith. ${ }^{10}$

Although the early rabbinic literature does not stray from the previously defined directions, the image of Lilith gets some more depth, while all her textual mentions can be partitioned into several thematic clusters. The first and the most developed one presents Lilith as a nocturnal she-demon. This is the case in BT Shabbath $151 \mathrm{~b}$, which discusses the restrictions emerging from the Sabbath obligations and states "[o]ne may not sleep in a house alone, and whoever sleeps in a house alone is seized by Lilith". This fragment in turn needs to be perceived in the broader framework outlined by BT Eruvin $18 \mathrm{~b}$ in which Adam begets myriads of evils spirits (Aram. ruchin and lilin), BT Sanhedrin 109a where one fraction of the builders of the tower of Babel is turned into "apes, spirits, devils and night-demons" (Heb. qophim ve-ruchot ve-shedim ve-lilin) and BT Berakhot 6a-b or BT Pesahim 112b which inhabit the world with legions of various hostile spirits. ${ }^{11}$ The second thematic cluster provides some details concerning the visual appearance of Lilith. Thus a lengthy teratological passage in BT Niddah 24b likens a miscarried fetus to Lilith on the grounds that they both have wings, ${ }^{12}$ while BT Eruvin $100 \mathrm{~b}$ speaks about ten curses put on woman ${ }^{13}$ and among them is that "she grows long hair" ${ }^{14}$ like Lilith, sits when making water like a beast, and serves as a

10 Douglas L. Penney and Michael O. Wise, "By the Power of Beelzebub: An Aramaic Incantation Formula from Qumran (4Q560)", Journal of Biblical Literature, Vol. 113, No. 4 (1994), pp. 630, 650. Note that in 11Q11 the word "Lilith" is conjectured.

11 Note however that all the sources use the masculine plural lilin. The feminine liliyot is not found in the early rabbinic literature.

12 The rabbis acknowledge two other types of deformations: the shapelessness (Heb. briyat guf she-'eyno chitukh - cf. "Amorpho", one of the epithets of Lilith according to James A. Montgomery, Aramaic Incantation Texts from Nippur, (Philadelphia: University Museum, 1913), p. 264) and the similarity to a serpent (Heb. dmut nachash). Rashi ad loc. explains that Lilith is a she-demon "who has a man's face and wings". If read against the backdrop of BT Hagigah 16a, such hybridity may witness to the supernatural origins of the child. Emil G. Hirsch, Solomon Schechter, and Ludwig Blau, "Lilith", in Jewish Encyclopedia, ed. Isidore Singer et al., (New York: Funk \& Wagnalls Co., 1902), http://www.jewishencyclopedia.com, accessed November 15 ${ }^{\text {th }}, 2015$.

13 The fragment is directly preceded by a case of a woman who solicits her husband to marital obligations. It is of question whether the subsequent curses should be read as the consequence of her deed. Burstein, Lilit..., p. 7.

14 Hair, along with voice, legs and little finger, was considered 'ervah, i.e. sexually arousing object in BT Berakhot 24a, cf. M Ketubot 7:6. Rebecca Lesses, "Exe(o)rcising Power: Women as Sorceresses, Exorcists, and Demonesses in Babylonian Jewish Society of Late Antiquity", Journal of the American Academy of Religion, Vol. 69, No. 2 (2001), pp. 357-358. The description of Lilith as a long haired woman finds some support in the imagery preserved in the Aramaic incantation bowls. Montgomery, Aramaic..., bowls no. 14, 15, 22, 26, pp. 321-326. 
bolster for her husband". The third cluster contains three passages that are difficult to classify. The first one appears in Numbers R. 16:25, which elaborates on the story in Exodus 14, and has Moses take sides with Israel and pledge before God so as he would not be like Lilith who kills her own children. ${ }^{15}$ The other one is present in a longer medical account in BT Gittin 69a-b mentioning a mysterious "arrow of Lilith", ${ }^{16}$ which was probably an antipyretic medicine. Finally, a passage in BT Bava Bathra 73a-b simply indicates a demonic figure of "Hormin the son of Lilith", without adding anything substantial about its nature. ${ }^{17}$ In sum then, the earliest Jewish textual evidence does not say much about Lilith apart from classifying her as a demon and investing her with some hybrid, theriomorphic features.

\section{Lilith in the Alphabet of Ben Sira}

The radical change in the image of Lilith occurs in the ABS, which is a Hebrew and Aramaic composition conceived between VIII and X CE and made of three essential parts. The first two sections contain the alphabetically arranged lists of proverbs supported by a running commentary and thus adhere to the traditional midrashic style. The third part, titled Toldot Ben Sira' (Eng. "Tales of Ben Sirach"), stands out from the rest of the book. The form changes to a hagiography relating the life and deeds of Joshua ben Sira, to whom the scholars usually attribute the authorship of the Jewish non-canonical Book of Wisdom also known as the Book of Ecclesiasticus. ${ }^{18}$ Content-wise however the text clearly ridicules the sapiential

15 Cf. Midrash Tanhuma Shelach. This description would also fit the Greek Lamia known for her taste in children.

16 Probably a meteorite stone or a fulgurite, colloquially known as petrified lightning. Especially the latter interpretation is interesting given the possible meaning of lil as "storm" or "tempest". Hirsch, Schechter, Blau, "Lilith". The Soncino Talmud, Gittin 69b, footnote numbers 1, 2.

17 Some of the BT manuscripts (e.g. Hamburg MS) have the word Hormiz and the variation may stem from the confusion of the final nun with zayn. Rashi ad loc. states that his version had Hormin but acknowledges the existence of the other variant. Hormiz in turn seems to be the distorted name of Ormuzd, the Zendavestan deity of light and goodness. The Soncino Talmud, Mas. Baba Bathra 73a, footnote number 29. If this interpretation is correct, then it is somewhat ironic that Ormuzd becomes the son of a nocturnal demon.

18 For the figure of Joshua ben Sira see: Moses Z. Segal, "Ben Sira, Simeon ben Jesus", in Encyclopedia Judaica, $2^{\text {nd }}$ Edition, eds. Fred Skolnik, Michael Berenbaum, vol. 3, (Detroit: Thomson Gale, 2007), p. 376. The academic consensus about the authorship of the Book of Wisdom of Sirach notwithstanding, it should be remembered that the work was conceived in a pseudepigraphic milieu and the explicit expression of the authorship should not be taken at face value. A very innovative approach to this problem is presented by Vicente 
and hagiographic genres by portraying the protagonist along with other noble biblical figures as indulging in sexual perversions, dealing with black magic and suffering from intestinal disorders. The satirical, ribald and even offensive vibe of the book has made some scholars believe, that the composition or at least this sole part originates in the circles hostile to the rabbinic culture - probably the Christian converts eager to despise their Jewish roots. ${ }^{19}$ Yet, whatever the provenance and purposes of the ABS, it goes without saying that it reiterates, though sometimes offensively, the traditions from the earlier Jewish sources.

These two facets of the composition have important implications in regards with the myth of Lilith which is contained precisely in the Toldot. The narration itself has the structure of the Chinese box: Nebuchadnezzar's son becomes ill, so the king asks Ben Sira to procure a remedy. The sage writes a special amulet containing the drawings and the names of three angels, "Snvi, Snsvi, and Smnglof" ${ }^{20}$ and when the king asks about the purpose of these, Ben Sira presents the amulet's historiola:

\begin{abstract}
After God created Adam, who was alone, He said, 'It is not good for man to be alone' (Gen. 2:18). He then created a woman for Adam, from the earth, as He had created Adam himself, and called her Lilith. Adam and Lilith began to fight. She said, 'I will not lie below,' and he said, 'I will not lie beneath you, but only on top. For you are fit only to be in the bottom position, while I am to be in the superior one.' Lilith responded, 'We are equal to each other inasmuch as we were both created from the earth.' But they would not listen to one another. When Lilith saw this, she pronounced the Ineffable Name and flew away into the air. Adam stood in prayer before his Creator: 'Sovereign of the universe!' he said, 'the woman you gave me has run away.' At once, the Holy One, blessed be He, sent these three angels to bring her back. Said the Holy One to Adam, 'If she agrees to come back, fine. If not she must permit one hundred of her children to die every day.'
\end{abstract}

\footnotetext{
Dobroruka, Second Temple Pseudepigraphy. A Cross-cultural Comparison of Apocalyptic Texts and Related Jewish Literature, (Berlin: Walter de Gruyter, 2014), especially pp. 86-108. The said scholar proposes reading this type of literature as an expression of the possessive experience, what makes the issue of authorship even more complicated.

19 For a scrupulous review of the most recent theories concerning the origins of the ABS see: Gili Orr, The medieval Alpha Beta de Ben Sira I ("Rishona"): A Parody on Rabbinic Literature or a Midrashic Commentary on Ancient Proverbs?, [PhD thesis], (Amsterdam: University of Amsterdam, 2009). Orr devotes a lengthy chapter for the scrutiny of the ABS's genre and classifies it as a parody (pp. 49-94).

20 These names appear in an unvocalized form. A classical exposition is found in Joshua Trachtenberg, Jewish Magic and Superstition: A Study in Folk Religion, (New York: Behrman's Jewish Book House, 1939), http://sacred-texts.com/jud/jms/index.htm, accessed November 15 $5^{\text {th }}, 2015$, p. 101. Moses Gaster noted an interesting parallel in the Byzantine legend of three righteous brothers Sinisius, Sines and Sinodorus who combat demoness Gello. Idem, "Two Thousand Years of a Charm against the Child-Stealing Witch", Folk-lore. Transactions of the Folk-lore Society, Vol. XI, No. II, (1900), p. 155. Alejandro A. Gonzáles Terriza found the further analogies in the Greek Library of Sathas 1876:573-5. Idem, Isis, Lilith, Gello: Three Ladies of Darkness, http://jewishchristianlit.com/Topics/Lilith/lillsisGylu.html, accessed November $15^{\text {th }}$, 2015, pp. 6-7. These angels also appear in Shimmush Tehilim ad Psalm 126 which is prescribed for the pregnant women.
} 
As is often the case with historiolas the story takes place in illo tempore ${ }^{21}$ and creatively reworks the motives from both of the Genesis anthropogenic accounts. Yet, whereas the biblical story remains rather restrained and humble, the ABS eagerly explores the intimate life of the first couple. ${ }^{22}$ After the fierce quarrel containing the unprecedented demands of gender equality, Lilith pronounces the Ineffable Name (Heb. ha-shem ha-mephorash) and escapes into the air. ${ }^{23}$ At first, this may look as if it is Lilith who becomes glorified for her strength, courage and expertise, since after all it is she who has the rare and rather masculine skill of doing wonders by means of the divine name. ${ }^{24}$ Yet, the ruthlessly parodic vibe of the Toldot suggests that the blade of criticism is actually directed against Adam who turns out to be weak and ineffective in relations with his wife. Apparently, the first man is not the only male figure who is mocked: even the Holy One cannot subjugate Lilith and needs to ask his messengers, who only manage to go as far as negotiating the conditions of agreement. All in all, Lilith is approached in her own dwelling by the divine emissaries, themselves a miserable reflection of the four majestic angels of the Enochian tradition, who descent to earth and pacify the rebels: ${ }^{25}$

21 Saul Shaked, "Form and Purpose in Aramaic Spells: Some Jewish Themes", in Officina Magica. Essays on the Practice of Magic in Antiquity, ed. Saul Shaked, (Leiden-Boston: Brill, 2005), pp. 1-30.

22 Although the text is ambiguous, the ribald context of the Toldot as well as the rabbinic euphemistic conventions suggests this interpretation. In regards with the latter see: Gail Labovitz, "Is Rav's Wife «a Dish»? Food and Eating Metaphors in Rabbinic Discourse of Sexuality and Gender Relations", Studies in Jewish Civilization 18: Love-Ideal and Real-in the Jewish Tradition, eds. Leonard J. Greenspoon, Ronald A. Simkins, Jean A. Cahan, (Creighton University Press, 2008), pp. 147-170. Still, the story lacks any clear parallel in the earlier rabbinic literature save for the account of the dispute between sun and moon which appears inter alia in Genesis R. 6:3-4, Kohelet R. 1:35, BT Hullin 60b and later in Zohar 1 20a. Stuart J. Moore, Myth and Motif: Lilith in Jewish Tradition, [term paper], 2006, https://www.academia.edu/11975779/Myth_and_Motif_Lilith_in_Jewish_Tradition, accessed November $15^{\text {th }}$, 2015 , p. 2.

23 González Terriza notes the similarity to the Egyptian myth of Isis tricking Ra into betraying his name by means of which he had created the world. An analogical account appears in a relatively late midrash Bereshit Rabbati 29 which has angel Shemhazai fall in love with Asterah who deceives him and learns the Ineffable Name necessary to ascend the heavens. Idem, Isis..., pp. 4-5.

24 Although the early rabbinic literature says little about the so called name magic, the later commentators read this feat into the text. Thus for instance Rashi attributes with this skill Betzalel, the divinely inspired builder of the Tent of Meeting (BT Berakhot 55a), the four rabbis who have entered the Pardes (BT Hagigah 14b; JT Hagigah 2:1) or Rabba who creates an artificial human (BT Sanhedrin 65b). It has to be remembered though that according to M Yoma 6:2 the name could be uttered only in the temple and during Yom Kippur, M Sanhedrin 10:1 deprives the one pronouncing it "in its letters" of the share in the world to come, while BT Qiddushin 71a recommends to substitute it with other appellations like 'Adonay (Eng. "my lords).

251 Enoch 6-11 and Jubilees 4-5. See also: Joseph Dan, "Samael, Lilith, and the Concept of Evil in Early Kabbalah", AJS Review, Vol. 5 (1980), p. 21, footnote number 18. 
The angels left God and pursued Lilith, whom they overtook in the midst of the sea, in the mighty waters wherein the Egyptians were destined to drown. They told her God's word, but she did not wish to return. The angels said, 'We shall drown you in the sea.' 'Leave me!' she said. 'I was created only to cause sickness to infants. If the infant is male, I have dominion over him for eight days after his birth, and if female, for twenty days.' When the angels heard Lilith's words, they insisted she go back. But she swore to them by the name of the living and eternal God: 'Whenever I see you or your names or your forms in an amulet, I will have no power over that infant.' She also agreed to have one hundred of her children die every day. Accordingly, every day one hundred demons perish, and for the same reason, we write the angels' names on the amulets of young children. When Lilith sees their names, she remembers her oath, and the child recovers.

The passage explains Lilith's eagerness to prey on the newborns ${ }^{26}$ and at the same time provides the rationale for the amulet's protective effectiveness. Thus, the contents of the ABS explicitly go against the previous traditions by portraying Lilith as interested in children and their mothers rather than in single men. ${ }^{27}$ In addition to this, two other unprecedented ideas appear. First, Lilith's breeding ground is apparently the biblical Yam Suf, the sea known from Exodus 15:4-5 and Jonah 2:6 and invested with some mythical undertones. ${ }^{28}$ Moreover, these "mighty waters" need to be perceived as a symbol of the chaoskampf, the primordial battle preceding the establishment of law and cosmic order. ${ }^{29}$ By turning it into Lilith's domain, the ABS seems to elevate her to the position of the ultimate enemy of God. Second, this association becomes even more apparent, if to acknowledge the tradition of Lilith as a perverted "mother of all life" responsible for begetting demonic legions, hundred of which is supposed to die every day. An obvious question arises, who was the father of these demons and this is in a way answered by an alternative ending of the story transmitted in some of the later manuscripts of the ABS:

26 Seven days for a boy correspond with the seven days of the impurity of his mother followed by the circumcision on the eighth (Leviticus 12:2-4). Still, there is no such parallel for the twenty days for a girl.

27 This tendency is typical for the birth amulets' historiolas. Montgomery, Aramaic ..., pp. 258-264. For a more modern example see: Margaretha Folmer, "A Jewish Childbirth Amulet for a Girl", in Studies in Hebrew Literature and Jewish Culture. Presented to Albert van der Heide on the Occasion of his Sixty-Fifth Birthday, eds. Martin F.J. Baasten, Reinier Munk, (Dordrecht: Springer, 2007), pp. 41-57. See also: Filomena Pereira, Lilith: the edge of forever, [MA thesis], (San Jose: San Jose State University, 1995), pp. 43-49.

28 Walter Wifall, "The Sea of Reeds as Sheol", Zeitschrift für die alttestamentliche Wissenschaft, Vol. 92, No. 3 (1980), pp. 325-332. Cf. the myth of Naamah, the she-demon of the great sea who steals men's semen and begets evil spirits (Zohar 3 76b-77a).

29 For a broad range of meanings associated with the concept of the mighty waters see: Stéphanie Anthonioz, "Water(s) of Abundance in the Ancient Near East and in Hebrew Bible Texts: A Sign of Kinship", in Thinking of Water in Judah, eds. Ehud Ben Zvi and Christoph Levin, (Berlin: de Gruyter, 2014), pp. 49-75. David Toshio Tsumura, "A Biblical Theology of Water. Plenty, Flood and Drought in the Created Order", in Keeping God's Earth: The Global Environment in Biblical Perspective, eds. Noah J. Toly and Daniel I. Block, (Downers Grove, IL: IVP Academic, 2010), pp. 165-184. 
They said to her: 'If you do not come back we shall drown you in the sea.' She answered: 'I cannot return because of what is said in the Torah -"Her former husband who sent her away, may not take her again to be his wife, after that she is defiled," [Deuteronomy 24:4] that is, when he was the last to sleep with her. And the Great Demon has already slept with me., ${ }^{30}$

Although the identity of this Great Demon (Heb. ha-shed ha-gadol) remains unknown, what ultimately counts is that Lilith becomes paired with a corrupted substitute for Adam, thus somewhat mirroring the first couple of the "mainstream" tradition. ${ }^{31}$

In result, the key-elements of the myth of Lilith as supplied by the ABS can be summarized as follows. (1) She is created as equal to man and becomes his first wife before Eve; (2) she possesses the knowledge of the divine name and its application; (3) she inhabits some desolate place, where (4) she engenders her own race of demons, probably with some substitute of Adam, and from where (5) she assaults the children unless they are protected by particular rites and paraphernalia.

\section{Eve in the Early Sources}

Obviously, the story in the Toldot tries to build up an appropriate etiology for the more ancient demonic lore. However, although the image of Lilith of the ABS is unprecedented, some of the particular elements of her portrayal can be traced back to the Talmudic and midrashic traditions arose around Eve. ${ }^{32}$ First and foremost, the very introduction of Lilith to the creation story was possible due to the rabbinic myth of two women. The latter in turn ultimately derives from the fact that Genesis 1:1-2:25 furnishes two separate creation accounts. In the first one, contained in 1:1-2:3, the process of cosmogony commences with the

30 After: Dan, Samael..., p. 22.

31 Joseph Dan supposes that the text hints at Samael, a heavenly accuser in Exodus R. 18:5; 21:7, inciter in Genesis R. 56:4-5 and the one responsible for the fall of humanity in Pirke de-rabbi Eliezer [PdrE] 12. The motif of Lilith and Samael as a perverted first couple appears in The Treatise on the Left Emanation and is later on incorporated in Zohar (1:19b-20a and 1:148a-148b). Dan, Samael... See also Zohar 1:55a and 3:76a which portray Lilith as a great seducer of humans, spirits and angels thus paraphrasing the tradition of the women beguiling the heavenly emissaries in Jubilees 4 . More examples of this misogynic twist in the myth of the fallen angels are furnished by: Kelley Coblentz Bautch, "What Becomes of the Angels' Wives? A Text-Critical Study of 1 Enoch 19:2," Journal of Biblical Literature, Vol. 125, No. 4 (2006), pp. 766-780.

32 For the detailed references to the primary rabbinic sources see: Tamar Kadari, "Eve: Midrash and Aggadah", in Jewish Women: A Comprehensive Historical Encyclopedia, http://jwa.org/encyclopedia/article/eve-midrashand-aggadah, accessed November $15^{\text {th }}, 2015$. 
creation (Heb. root bara') of earth and heavens and lasts six days, with the seventh devoted to the divine rest. In the second one, accommodated in 2:4-2:25, the earth and heavens are already made and the deity forms (Heb. root yatzar) a man to take care of it, while the span of the whole work remains undefined. Both narratives differ in terms of anthropogony as well. According to the first one in Genesis 1:26-28, male and female (Heb. zakhar u-neqevah) are brought to life simultaneously in the image and after the divine likeness and thus become the crown of creation. Meanwhile in Genesis 2:7 Adam is formed out of the dust, animated with the divine breath and only later in v. 21-23 provided with a woman (Heb. 'ishah) made out of his rib. One way of resolving the outward discrepancy ${ }^{33}$ between these two accounts was to assume that there must have been some other woman apart from the one later on identified with Eve. In fact, this is the exegetical strategy taken by the rabbis who paid a special attention to Adam's exclamation in Genesis 2:23: "this time (Heb. zot ha-pa'am) [this is] bone of my bone and flesh of my flesh". ${ }^{44}$ The chazalim took this as a clear suggestion that the "first time" must have taken place already, for according to Genesis R. 18:4 Adam was disgusted by seeing the first woman full of "discharge and blood" and God had to provide him with another one. The subsequent creation is performed with adequate precautions: Adam is made asleep so as not to witness the process itself (BT Sanhedrin 39a), Eve is adorned with fine jewelry (Genesis R. 18:1) and brought to Adam by angels Gabriel and Michael (Genesis R. 18:3). Yet, nowhere do the rabbis specify what has happened to the first woman and the matter remains opened for the further speculations - and this is the gap, where the later tradition of Lilith could have been put.

\footnotetext{
33 Some argue that these differences were not a problem for the early exponents as is suggested by simple combination of Genesis 1:27 with 2:24 in Matthew 19:3-9 and Mark 10:2-9. C. John Collins, "Adam and Eve in the Old Testament", The Southern Baptist Journal of Theology, 15.1 (2011), pp. 8-9.

34 Own translation. See also BT Yevamoth 63a: "R. Eleazar further stated: What is meant by the Scriptural text, This is now bone of my bones, and flesh of my flesh? This teaches that Adam had intercourse with every beast and animal but found no satisfaction until he cohabited with Eve." Despite the apparent "indecency" of this tradition, it has been transmitted by Rashi ad Genesis 2:23 and as such has gained widespread popularity. Eric Lawee, "The Reception of Rashi's Commentary on the Torah in Spain: The Case of Adam's Mating with the Animals", The Jewish Quarterly Review, Vol. 97, No. 1 (2007), pp. 33-66.
} 
Second, this new woman still meets with harsh rabbinic allegations and Genesis R. 18:4 attributes her with some negative traits, basing on the wordplay with the phrase zot hapa'am. According to the words of Adam, she "is destined to strike the bell and to speak [in strife] against me, as you read «a golden bell (Heb. pa'amon) and a pomegranate» (Exodus $28: 34)$ "35 and "it is she who troubled me (Heb. me-fa 'amtani) all night". In addition to this, the first woman becomes the object of accusations ascribed to rabbi Joshua of Siknin. In Genesis R. 18:2 he says that despite the divine efforts, Eve turned out to be "swelled-headed, coquette, eavesdropper, gossip, prone to jealousy, light-fingered and gadabout". ${ }^{36}$ A similar set of charges is provided in Genesis R. 17:8, according to which the fact, that Eve is created from rib rather than earth, makes her inferior to Adam and never satisfied with anything. Still however, all these blames remain rather mild in comparison to the gravest evils associated with Eve in Genesis R. 17:8:

Why does a man go out bareheaded while a woman goes out with her head covered? She is like one who has done wrong and is ashamed of people; therefore she goes out with her head covered. Why do they [the women] walk in front of the corpse [at a funeral]? Because they brought death into the world, they therefore walk in front of the corpse, [as it is written], "For he is borne to the grave... and all men draw after him, as there were innumerable before him" (Job 21:32 f). ${ }^{37}$ And why was the precept of menstruation given to her? Because she shed the blood of Adam [by causing death], therefore was the precept of menstruation given to her. And why was the precept of "dough" given to her? Because she corrupted Adam, who was the dough (hallah) of the world, therefore was the precept of dough given to her. And why was the precept of the Sabbath lights given to her? Because she extinguished the soul of Adam, therefore was the precept of the Sabbath lights given to her. ${ }^{38}$

35 The expression "to strike a bell" can be interpreted as "to bring charges and accusations". The Soncino Midrash Rabbah, p. 141, footnote number 4. It seems however that the original in Hebrew goes much deeper. It says zot hi', she-'atidah lehaqish 'alay ke-zog what can be rendered as "this is she, who will hit me like a bell" (own translation). The hook is in the Heb. word zog which means an external part of the bell or the bell in toto. If written without the vowel marks, the word is identical to zug which means a couple. By utilizing this particular expression the rabbis could introduce the semantic wordplay with pa 'amon (Eng. "bell") and the phonetic wordplay with zug. Avraham Even Shoshan, "zog" and "zug" in Ha-Milon He-Chadash, (Jerusalem: Kiryath Sepher, 1979), vol. 2, p. 658. In addition to this, the text features the phrase from Exodus $28: 34$ "a golden bell and a pomegranate". These elements appear as an ornamentation of the high priest's robe and one could wonder whether the rabbis imagined the wife as the constantly tinkling bell and the husband as the quiet pomegranate. I would like to thank one of the anonymous reviewers for directing my attention to the problem.

36 Cf. analogical accounts in Genesis R. 80:5 and Deuteronomy R. 6:11. A similar misogynist twist is present in other places as well. For instance, in Genesis R. 17:4 God foresees the problems caused by Eve and delays her creation until Adam explicitly demands her while in BT Bava Bathra 58a Eve's beauty cannot match that of Adam. Another tradition has it that after having realized her sin, Eve purposely tricks her husband into eating the fruit (Genesis R. 19:5; PdrE 13) or adds it to his wine (Numbers R. 10:4).

$37 \mathrm{Cf}$. BT Berakhot 51 a stating that one should not cross the road of women returning from a funeral since they are preceded by the angel of death who leaps and cuts whomever he finds on his path. See also: Genesis R. 17:6 according to which the creation of Eve parallels the introduction of Satan to the world.

38 Cf. M Shabbath 2:6 and JT Shabbat 5b which explain three women's precepts (niddah, hallah and nerot shabbat) as stemming from the sins of Eve. For other "consequences" of Eve's deeds in the sphere of halakhah 


\section{Eve and (the Angel of) Yahveh}

Third and despite the biblical laconism in this regard, among the iniquities attributed to Eve these of the erotic nature constitute a separate category. For the starters, the rabbis base on Genesis 3:16 which reads "your desire ${ }^{39}$ shall be for your husband" and accuse her of an overdeveloped sexual drive (Genesis R. 20:7) and permanent incitement of Adam (Genesis R. 23:5). These allegations however are generic and unspecific, while the most important traditions stem from the exposition of Genesis 4:1. According to the verse, right after giving birth to Cain, Eve says: "I have gotten a man with the help of the Lord". The problematic sentence in the Hebrew original reads qaniti 'ish 'et Yahveh and apart from being an obvious pun with the name of the newborn, it features two essential linguistic anomalies. First, the verb qana' in most modern English translations is rendered as "acquired" or "got". In the Biblical Hebrew however the verb could also convey the meaning of creation which is reflected in the divine epithet qoneh shamaym va-'aretz (Eng. "creator of heavens and earth") in Genesis 14:19, 22, the phrase Yahveh qanani (Eng. "Yahveh has created me") in Proverbs 8:22 or the expression $k i$ 'atah qanita kilyotay (Eng. "because you have created my kidneys") in Psalm 139:13. ${ }^{40}$ The second anomaly concerns the word 'et in the phrase 'et Yahveh which would normally, i.e. in terms of frequency, serve as the marker of the accusative case. Here however, due to the construction of the phrase, 'et probably has to be interpreted as "with" and Eve's utterance taken as a whole suggests that it is Yahveh with whom she begets Cain. ${ }^{41}$

see: Eric Ottenheijm, "Eve and 'Women's Commandments' in Orthodox Judaism Perspective, in Out of Paradise. Eve and Adam and Their Interpreters, Bob Becking and Susan Hennecke (eds.), (Sheffield: Phoenix Press, 2010), pp. 157-173. Interestingly, some later sources like Avot de-rabbi Nathan blame Adam for not educating Eve and distorting the divine command. Marcel J.H.M. Poorthuis, "Who Is to Blame: Adam or Eve? A possible Jewish source for Ambrose's De paradiso 12,56", Vigiliae Christianae, Vol. 50, No. 2 (1996), p. 129.

39 Heb. tshuqah. As brilliantly shown by Joel N. Lohr, although the term denotes "return" rather than "desire", the semantic overlap between the two is apparent. Idem, "Sexual Desire? Eve, Genesis 3:16, and "תשוקה", Journal of Biblical Literature, Vol. 130, No. 2 (2011), pp. 227-246.

40 Own translation.

41 For a detailed analysis of the semantic potential of the Heb. root qanah against its meaning in other Semitic languages see: David E. Bokovoy, "Did Eve Acquire, Create, or Procreate with Yahweh? A Grammatical and Contextual Reassessment of קנה in Genesis 4:1", Vetus Testamentum, No. 63 (2013), pp. 19-35. 
At first glance this seems to go against the verse's opening which reads "Now Adam knew Eve his wife, and she conceived and bore Cain". The problem is however, that this portion appears as if it was a later addition to the rest of the text, because it starts with the subject (Heb. ve-ha-'adam yada' 'et Chavvah 'ishto) rather than with the verb (Heb. va-yeda' ha-'adam 'et Chavvah) as do the other such sentences in Genesis 4:17,25. ${ }^{42}$ In addition to this, it is remarkable that Eve is the first person in the HB to utter the tetragrammaton aloud and this goes explicitly against the later traditions in Exodus 3:15 and 6:3, according to which Yahveh revealed his "real" name only to Moses. ${ }^{43}$

However uncanny it may sound at first, the above presented instance of human-divine cohabitation is not out of place in its context. Genesis 6:1-4 furnishes a tale of the sons of God (Heb. bney ha-'elohim) who come down and mate with the earthly women. Less explicit but still suggestive is the account in Genesis 21:1 which has Yahveh "attend" (Heb. paqad) Sarah and "do" to her (Heb. 'asah) what he had announced earlier thus making her pregnant in v. $2 .{ }^{44}$ In a similar vein is the passage in Judges 13:2-24 describing the birth of Samson. An angel of Yahveh shows up (Heb. ra 'ah, v. 3) to Manoah's wife and comes (Heb. bo', v. 9) to her in the plains, what results in the conception and birth of the Israelite hero (v. 24). ${ }^{45}$

In sum, the syntactic awkwardness of the verse, the choice of vocabulary and other biblical instances of human-divine cohabitation taken together are clearly suggestive of the

42 Thus, the verse would sound more naturally beginning with the words va-tahar va-telekh 'et Qayn, i.e. "and she conceived and bore Cain".

43 The knowledge of the tetragrammaton is also attributed to Abram in Genesis 14:22. I would like to thank one of the anonymous reviewer for reminding me this fact. For the review of scholarly attempts at compromising this discrepancy see: Geoffrey H. Parke-Taylor, Yahweh: The Divine Name in the Bible, (Ontario: Wilfrid Laurier University Press, 1975), pp. 18-45.

44 Heb. va-tahar va-telekh Sarah. Note the linguistic similarity to Genesis 4:1. The name of the son, Isaac, seems to be of significance here as well, given the euphemistic undertone of the verb tzachaq as is the case in Genesis 26:8 which has the patriarch "entertain" (Heb. metzacheq) his wife.

45 Numerous other examples are gathered in: Avigdor Shinan and Yair Zakovitch, From Gods to God. How the Bible Debunked, Suppressed, or Changed Ancient Myths and Legends, (Lincoln: Nebraska University Press, 2012), pp. 27-34. The ancient Near Eastern literary context of the HB furnishes even more accounts of the carnal encounters between deities and humans. This is the case with the parents of Gilgamesh (Epic of Gilgamesh I.46 and IX:51) or El and an earthly woman begetting Shahar and Shalem (KTU 1.23). Daniel Bercerra, "El and the Birth of the Gracious Gods", Studia Antiqua, Vol. 6, No. 1/2008, pp. 51-56. Last but not least, it is important to note the broad hermeneutic possibilities provided by the Hebrew sexual euphemisms. In this regard see: Edward Ullendorf, "The Bawdy Bible", Bulletin of the School of Oriental and African Studies, University of London, Vol. 42, No. 3/1979, pp. 425-456. 
sexual relations between Yahveh and Eve. Obviously, the early translators and exegetes must have found this idea unsettling and tried to substitute Yahveh with other creatures in subsequent retellings. ${ }^{46}$ Thus, in Targum Pseudo-Jonathan [TPJ] to Genesis 4 God is replaced by the angel of Yahveh while in PdrE 21 - by the angel Samael riding on the serpent. And if the issue of human-divine relation was not enough, there are several reasons to assume that it is Eve who later on becomes her firstborn's wife in Genesis 4:17. The chapter lacks any other viable candidate for this role, while the post-biblical reiterations contain some suggestive hints. Thus, Jubilees 4:9 names the wife of Cain as Awan, what in itself appears to be a distortion of "Eve", while midrash Genesis R. 22:7 has Cain and Abel fight for the right to marry "the first Eve". ${ }^{47}$

\section{Eve and the Serpent}

However, in terms of the textual popularity and spread, it is the motive of Eve copulating with the primeval serpent that has the priority over the remaining sexual transgressions. According to the story, the snake gazed at Adam and Eve, when they were making love, developed desire for the first woman, mated with her and tainted her with the uncleanness (Aram. zohama'). ${ }^{48}$ Eve in turn, as the mother of all life, transmitted this contamination to the subsequent generations and it was only due to the presence of the Israelites in front of the Mount Sinai that they have been purified - unlike the other nations who remained polluted. Despite the rather unsettling picturesqueness of this account, it is conveyed in numerous places: Genesis

\footnotetext{
46 Contra: Genesis R. 22:2 claiming that the participation of God is a necessary condition of every conception. See also BT Sanhedrin 96a which has Laylah the angel (note the homoiophony with "Lilith") intercept the seed ejaculated during the coitus and bring it to heavens in order to decree the fate of the child.

47 Here the expression "the first Eve" refers most probably to the biblical Eve rather than to Lilith. Kocku von Stuckrad, Constructing Femininity - the Lilith Case, http://www.richarddagan.com/10.1.1.93.2673.pdf, accessed November $15^{\text {th }}, 2015$, p. 10. Cf. the incest story of Lot and his daughters in Genesis 19:30-38. Nicolas Wyatt, "Cain's wife", Folklore, Vol. 97, No. 1 (1986), pp. 88-95. Idem, "Eve", in DDD, p. 317.

48 This is not at all surprising given the fact, that according to the rabbinic classifications the serpent belongs to the 'avot ha-tuma'ot - "the fathers of uncleanness", i.e. the primary sources of impurity. See: Leviticus 11:3335; Numbers 19:14-18; M Kelim 1:1-4.
} 
R. 18:6, BT Sotah 9b, BT Shabbath 196a, BT Yevamoth 103b, BT Shabbath 145b-146a and BT Avodah Zarah 22b. ${ }^{49}$

The tradition of Eve making love with the serpent and transmitting the impurity is particularly striking for two reasons inherently connected to the etymology of her name. Although the Heb. Chavvah is of unknown provenance and the contemporary academics tend to treat is as a loan-word, the older scholarship was marked by the search for the "native" Hebrew origins through the biblical and rabbinic puns. ${ }^{50}$ Somewhat surprisingly, given the rabbinic eagerness to engage in a variety of wordplays on the one hand and the inherent paronomastic potential of the name Chavvah on the other, ${ }^{51}$ the HB and the early rabbinic literature documents only two such instances. Thus, the first such etymological hypothesis bases on the wordplay in Genesis R. 20:11 which has Rabbi Aba interpret the meaning of Chavvah as follows: "the serpent is your serpent - and you are Adam's serpent" 52 (Aram. chivviya' chivviyakh - ve-'at chivviya' de-'Adam). Obviously, this wordplay is applied with a clear purpose of presenting the first woman as the main reason behind Adam's fall and as such it classifies as a folk etymology. Yet, its rabbinic ideological usage notwithstanding, some scholars like Julius Wellhausen and Theodor Nöldeke argued for the pun's etymological relevancy. Meanwhile, Morris Jastrow based on a hypothesis that Genesis 3:20 is a later addition to the text, intended to connect the mysterious creature of Genesis 4:1 known only as chavvah with the woman (Heb. 'ishah) of Genesis 3, and asked: “[i]s it not possible, therefore, that «the serpent» was originally and in reality merely the woman who, by arousing the sexual passion, leads man to a «knowledge of good and evil»?". ${ }^{33}$

49 A somewhat tempered version of this story appears in Apocalypse of Moses 19-20, where Satan injects the fruit with lust (Gr. epithymia).

50 For a review of hypotheses see: Howard N. Wallace, "Eve", in The Anchor Bible Dictionary, ed. David Noel Freedman, (New York: Doubleday, 1997), (CD-ROM). Wyatt, Eve..., p. 316. The references to the older scholarship can be found in: Frederick Robert Tennant, The Sources of the Doctrines of the Fall and Original Sin, (Cambridge: Cambridge University Press, 1903), p. 26, footnote number 2.

51 For instance with the word havvah (Eng. "ruin" or "misery") in Psalm 91:3, 'eyvah (Eng. "enmity") in Genesis 3:15 or with to 'evah (Eng. "abomination") in Leviticus 18:22.

52 Own translation.

53 Morris Jastrow, “Adam and Eve in Babylonian Literature”, The American Journal of Semitic Languages and Literatures, Vol. 15, No. 4 (1899), pp. 209-211. 
This hypothesis is all the more interesting given the distinguished position of the serpent in the biblical mythology of Yahveh. Suffice it to note, the guardian seraphs of Isaiah 6:1-6, the agents of the divine anger and the healing artifact in Numbers 21:4-9, an ancient idol destroyed by king Hezekiah in 2 Kings 18:4:2-4, Moses' "caduceus" in Exodus 4, and "Leviathan, the fleeing serpent" - the main antagonist in the chaoskampf myth in Isaiah 27:1 and Yahveh's pet in Ps 104:26. ${ }^{54}$ Finally, these and the other appearances of the snake in Yahveh's close entourage has led some academics to assume that this might be the deity's theriomorphic manifestation. ${ }^{55}$ If the scholars are right in supposing that the figure of snake was inherently important at least in the early period of Yahvism, then one has a solid reason to assume that the serpentine connections of Eve go even further than what is found in the rabbinic retellings.

\section{Eve as the Mother of All Life}

The second etymological hypothesis bases on the wordplay present in Genesis 3:20, in which Adam called his wife Chavvah, because she was the mother of all living creatures (Heb. 'em kol chay). From this perspective, Chavvah would be a derivation from the root chet-yod denoting life or a living thing and as such would suggest that the main function of Eve is to give birth. Eve's sobriquet evokes obvious associations with similar epithets of the ancient Near Eastern mother-goddesses. The richest comparative material comes from Mesopotamia and includes the divine Mami known as "the mistress of all gods" and "the creatress of humanity", the serpent-nymph Siduri guarding the divine vineyard at the source of the heavenly rivers, the woman-prostitute who introduces Enkidu into culture and Sumerian Ninti known as the "the lady of life" or "the lady of rib". No less important is the Canaanite

54 Yair Zakovitch, "Nechashim, Miqdashim, Lechashim u-Nashim", in Migvan De'ot u-Hashqafot 'al haNachash be-Pardes, ed. Dror Kerem, (Jerusalem: Ha-Minhal le-Chinukh Hityashvuti ve-'Aliyat ha-No'ar baMisrad ha-Chinukh ha-Tarbut ve-ha-Sifrut, 1998), http://mikranet.cet.ac.il/pages/item.asp?item=16205, accessed November $15^{\text {th }}, 2015$.

55 Oskar Goldberg, Rzeczywistość Hebrajczyków, tr. Tomasz Sikora, (Kraków: Nomos, 2012), pp. 192-197. 
evidence containing such parallels as the goddess Qudshu represented as a naked woman with a snake, Asherah known by her Ugaritic epithet "the creatress of gods" or "the nurse of gods" and the Hurrian deity Hebat, the consort of Teshub, the storm god. ${ }^{56}$ Finally, the rabbis themselves note the similarities between Eve and mother goddesses present in other religious traditions in BT Avodah Zarah 43a. In sum, this all suggests that her initial status might have been more important than just a regular woman and a humble wife of Adam.

This second etymological hypothesis is all the more interesting given the above presented traditions of Eve transmitting the serpentine impurity to the subsequent generations. Accordingly, in several places including Genesis R. 20:11; 24:6 and BT Eruvin 18b it is said that right after the crime of Cain, the first couple decided to withhold from copulation for 130 years. During this period of chastity both Adam and Eve became sexually assaulted by the hostile spirits who beget with them even more demons. These in turn filled the earth and have plagued the mankind since then. As it turns out, Eve's appellation of Genesis 3:20 gets here its ambivalent yet fully consequent extension: not only is she the mother of Cain, Abel and Seth, but she also begets a myriad of fiendish monsters. This is a mother of all life indeed.

In sum then, Eve is said to be of unquenchable desire (Genesis 3:16; Genesis R. 20:7; 23:5) and, depending on the particular interpretation, copulates with Yahveh (Genesis 4:1), angel of Yahveh (TPJ to Genesis 4:1), angel Samael (PdrE 21) or the primeval serpent (Genesis R. 18:6, BT Sotah 9b, BT Shabbath 196a, BT Yevamoth 103b, BT Shabbath 145b146a, BT Avodah Zarah 22b) - not to mention the hint of some intimacy between her and Cain (Genesis R. 22:7). The moniker of Eve as "the mother of all living creatures" is somewhat perverted when she is said to be the progenitress of all the demons invading

56 For the classical presentation of the subject see: Raphael Patai, The Hebrew Goddess, (Detroit: Wayne State University Press, 1990). Particular parallels are examined in: William F. Albright, "The Goddess of Life and Wisdom”, The American Journal of Semitic Languages and Literatures, Vol. 36, No. 4 (1920), p. 284. John A. Bailey, "Initiation and the Primal Woman in Gilgamesh and Genesis 2-3", Journal of Biblical Literature, Vol. 89, No. 2 (Jun., 1970), p. 137. Jastrow, Adam..., pp. 197-204, 208, 211-213. Karen Randolph Joines, The Bronze Serpent in the Israelite Cult, "Journal of Biblical Literature" 87 (1965), pp. 246-250. Isaac M. Kikawada, "Two Notes on Eve", Journal of Biblical Literature, Vol. 91, No. 1 (Mar., 1972), pp. 33-37. Karel van der Toorn, "Hebat", in DDD, pp. 391-392. Wyatt, Eve..., p. 316. 
humanity (Genesis R. 20:11; 24:6; BT Eruvin 18b). In addition to this, Eve as the paradigm for all the women, gathers the worst character traits: she is quarrelsome, annoying (Genesis R. 18:4), swelled-headed, coquette, eavesdropper, gossiper, prone to jealousy, light-fingered and gadabout (Genesis R. 18:2; Genesis R. 80:5; Deuteronomy R. 6:11). She is also responsible for corrupting Adam, the crown of the divine creation (Genesis R. 17:8) and in such context, the biblical transgression of the divine command not to eat the fruit from the tree of knowledge of good and evil (Genesis 3:1-6) seems to be the least grave. Finally, Eve is the first person in the HB who proves the knowledge of the tetragrammaton (Genesis 4:1).

\section{Eve and Lilith - a Comparison}

The similarities and differences between Eve and Lilith now become apparent. Both women are portrayed as the first females on earth with the narrative of Lilith obviously utilizing the midrashic tradition of the imperfect wife of Adam. Yet, while Eve is definitely inferior to her male counterpart serving him as a helper according to Genesis 2:20-21, Lilith is made as equal to Adam, thus somewhat paraphrasing the first creation account of Genesis $1: 1-2: 3{ }^{57}$ Interestingly, both women remain in close relationships with the divinity and know the Ineffable Name of God, yet only Lilith makes an explicit use of this knowledge. The other interesting distinctness concerns their relation to Adam. Both women afflict him, but then again, while Lilith simply escapes from her husband, possibly exposing him to a mild sexual frustration, Eve brings on the first man far more grim consequences. Most importantly however, one and the other woman is construed first and foremost as a sexual and reproductive object. ${ }^{58}$ Although the biblical account remains rather unassuming in this regard,

57 Diana Carvalho, Woman Has Two Faces. Re-Examining Eve and Lilith in Jewish Feminist Thought, (Denver: University of Denver, 2009), [MA thesis], p. 25.

58 Still, this seems to be the default way of portraying women in the HB or in the literature and iconography of the ancient Near East in general. See: Elizabeth Bloch-Smith, "Acculturating Gender Roles: Goddess Images as Conveyors of Culture in Ancient Israel”, in Izaak J. de Hulster, Joel M. LeMon (eds.), Image, Text, Exegesis. Iconographic Interpretation and the Hebrew Bible, (London et al.: Bloomsbury T\&T Clark: 2015), pp. 1-18. Rachel Havrelock puts it bluntly: "the procreative context is the only one which allows for a direct communication between woman and YHWH (or his messenger)". Idem, "The Myth of Birthing a Hero: Heroic 
the later rabbinic traditions leave no doubts about the basic role of Eve. The ABS in turn starts the whole story of Lilith with a glimpse into the alcove of the first couple. Interestingly, the women differ in terms of their carnal appetites with Lilith being far less interested in sex than in afflicting the newborns. On the other hand, according to the early exegetical speculations, from the two it is Eve who is presented as far more lascivious than Lilith - at least as far as the number of possible lovers is the criterion. Finally, the two are also the archetypal foremothers. However, the main difference in this regard lies in the fact that Lilith begets only evil demons, whereas Eve brings about both regular humans and malevolent spirits. Yet, from this perspective, the Lilith-passages of the ABS appear far less surprising: Lilith who copulates with the Great Demon and begets myriads of evil spirits in a way repeats the deeds attributed to Eve in much earlier literature. In other words, Lilith as portrayed in the ABS remains in the semantic framework defined by her "older" sister.

Still, not every quality of Eve finds its exact realization in Lilith. The most vivid difference between these characters lies in the negative traits attributed to them. While Eve is portrayed as accumulating all the flaws one can think of, the main fault of Lilith is insubordination to her male company. Also, the things differ when it comes to their emancipation. Although Eve is involved in more serious crimes, she utters just a couple of words throughout her literary career in the early sources and remains mute for the most of the time. In fact, the only explicit expression of her aspirations would be the episode with the serpent from Genesis 3, where she gets lured by the possibility of becoming like God. On the other hand, it is Lilith who not only manifests her attitude, but decides for her own, thus going explicitly against the will of her husband, angels and even God himself. In other words, whereas Eve surpasses Lilith in terms of the range and caliber of the sins she commits, it is Lilith who, although transgressive, still manages to remain far more independent and individual, even at the cost of conflicting with her male company. In addition to this, while Barrenness in the Hebrew Bible", Biblical Interpretation, 16/2007, p. 156. 
Eve, the mother of all humans, is portrayed as possessing both positive and negative traits, nothing flattering is said about Lilith. In result it is Lilith who appears to be far less ambivalent and more defined than Eve.

\section{Conclusions}

This brings us directly to the question, what is the function behind the Lilith-myth of the ABS. As has already been noted, most scholars construe it as an elaborate historiola explaining the newborns' deaths, justifying the production of the appropriate protective amulets and legalizing the usage of such paraphernalia within the Jewish religion. In other words, the text utilizes the motifs from the earlier sources and incorporates the myth of Lilith into the broader framework. ${ }^{59}$ Yet, this interpretation has at least three weak spots. First and foremost, one could wonder whether the Lilith amulets actually needed any additional rationale. In fact, the earlier rabbinic Judaism had few problems with the broadly understood category of amulets and it was only a minority of the medieval Jewish sages that opposed their usage. The BT has a general category for amulets (Heb. qame'ot, literally "something bound") as well as the names for the specific types of charms (e.g. Heb. segulot), directed against particular evil spirits (e.g. Pesachim 111b). In general, the rabbis approved of making and using such paraphernalia, as long as they came from a professional and proved efficacious three times in a row for three different persons (M Shabbath $6: 2$; BT Shabbath $61 \mathrm{~b}$ ) ${ }^{60}$ From this perspective, the additional attempts to "legalize" the Lilith amulets seem rather redundant. Second, although the ABS has enjoyed a great popularity, ${ }^{61}$ its satirical tone might have seriously affected the perceived effectiveness of the Lilith amulets and it is questionable, whether such work could be taken as supporting the usage of this kind of paraphernalia. If the

59 See for instance: Maria Fernandes, "Lilith: From Powerful Goddess to Evil Queen", in Revisitar o mito = Myths revisited, ed. Abel do Nascimento Pena, (Ribeirao: Húmus, 2015), p. 734. Gershom Scholem, Kabbalah, (New York: Penguin Group, 1978), p. 357. Eli Yassif, after: Burstein, Lilit..., pp. 10-11.

60 Ludwig Blau, “Amulet”, in Jewish Encyclopedia, eds. Isidore Singer et al., (New York: Funk \& Wagnalls Co., 1902), http://www.jewishencyclopedia.com, accessed November $15^{\text {th }}, 2015$.

61 Orr, The Medieval..., pp. 1-2. 
hypothesis about the origins of the ABS among the Jewish converts is right, then the purpose of the story might have been simply to portray the Jews as the amulet makers. ${ }^{62}$ Third, the very fact that the story plays with the motif of charms, is opened to at least two lines of interpretation. The account may provide the rationale for the usage of such artifacts, but it can also be utilizing an existing and widespread tradition of Lilith birth-amulets in order to promote a new story of the first wife of Adam. Thus, whatever the reason behind the ABS, the narrative strays from the previous traditions of Lilith and constructs her new image by resorting to the mythology of Eve.

Thus, it is striking that from among many other female figures of the early Jewish tradition the text chooses exactly Eve. Although it cannot be said with certainty that this was the main purpose of the ABS, the actual result is that Lilith as presented in the ABS helps to "distract" the hermeneutic attention from the actual linguistic problems evoked by Genesis 3: is Eve identical to the first woman? were not Eve and the serpent initially one figure? did Eve, whatever her nature, coupled with Yahveh so as to give birth to Cain, the first human? The relatively late invention of the Lilith-tradition may have helped to consolidate the image of Eve as the wife of Adam and mother of Cain despite the inherent textual ambiguities. In addition to this, Lilith of the ABS took over some of the negative qualities of her older sister and became her vivid and unequivocal counterpart. This interpretation finds its precedence in the patterns present in the earlier Jewish sources, according to which one character unburdens the other. This is particularly apparent in the accounts which introduce an angel or some other creature who replaces God in his morally ambivalent actions. Such instances in turn can be found in the HB (e.g. Genesis 22, 2 Samuel 24) as well as in the post-biblical reiterations (e.g. Exodus R. 5:8 or BT Nedarim 31b-32a retelling Exodus 4:24-26) ${ }^{63}$

62 See: Trachtenberg, Jewish Magic..., pp. 139-145.

63 The biblical instances are best explained by means of the interpolation theory advanced by Samuel A. Meier, "angel of Yahweh", in DDD, pp. 53-59. Idem, angel I, ibidem, pp. 45-50. For the relatively recent evaluation of the interpolation theory see: Wojciech Kosior, "The Angel in the Hebrew Bible from the Statistic and Hermeneutic Perspectives. Some Remarks on the Interpolation Theory", The Polish Journal of Biblical Research, Vol. 12, No. 23 (1/2013), pp. 55-70. Worth noting here is the figure of Azazel of Leviticus 16 who 
In sum then, the legend of Lilith as supplied by the ABS helps to resolve or at least distract from numerous problems inherent to the earlier traditions. Most importantly however - at least from the perspective of the role-modeling function of the biblical characters - Lilith helps at promoting a relatively positive image of Eve. In result, without Eve there would be no Lilith since it is Eve who is textually older than Lilith and to whom the latter owes her symbolical career. Moreover, it is Eve, or her hypothetical previous image that is far more ambivalent and disturbing than that of Lilith and most of what Lilith does in the ABS, Eve had done centuries before. ${ }^{64}$

\section{References}

\section{Primary Sources:}

Alphabet of Ben Sira, in D. Stern, M.J. Mirsky, Rabbinic Fantasies: Imaginative Narratives from Classical Hebrew Literature, Philadelphia, Jewish Publication Society, 1990, p. 183184.

Hebrew Bible [Codex Leningradensis], in: BibleWorks 9.0 (CD-ROM).

The English Standard Version Bible, [online], http://www.esvbible.org/.

Pirke de rabbi Eliezer (The Chapters of Rabbi Eliezer the Great), tr. G. Friedlander, London 1916.

\footnotetext{
becomes the fallen angel ultimately responsible for the corruption on earth in later apocrypha and pseudepigrapha. In this regard see the scholarship of Andrei Orlov: Dark Mirrors: Azazel and Satanael in Early Jewish Demonology, (New York: SUNY Press, 2011) and Divine Scapegoats: Demonic Mimesis in Early Jewish Mysticism, (Albany: SUNY Press, 2015).

64 Interestingly, similar conclusions though in regards with other child-stealing demons (Lamia, Gello and Mormo) and in the different methodological context are reached by Camilla Asplund Ingemark and Dominik Ingemark, "More than Scapegoating. The Therapeutic Potential of Stories of Child-Killing Demons in Ancient Greece and Rome", in Therapeutic Uses of Storytelling: An Interdisciplinary Approach to Narration as Therapy, ed. Camilla Asplund Ingemark, (Lund: Nordic Academic Press, 2014), pp. 75-84. The authors claim that the transmission of guilt to the supernatural beings "averted the socially disruptive consequences of imputing blame to family members, or accusing neighbors of witchcraft" (p. 78). Worth mentioning here is also the psychoanalytical concept of splitting, i.e. apprehending a given object, composite and ambivalent by nature, in a binary manner. This idea found its fruitful application in the mythological hermeneutics of Bruno Bettelheim. He writes about the tale of Little Red Riding Hood: "Unable to see any congruence between the different manifestations, the child truly experiences Grandma as two separate entities - the loving and the threatening. She is indeed Grandma and the wolf. By dividing her up, so to speak, the child can preserve his image of the good grandmother. If she changes into a wolf-well, that's certainly scary, but he need not compromise his vision of Grandma's benevolence." Bruno Bettelheim, The Uses of Enchantment, (Vintage Books, 1976/2010), (e-book). Mutatis mutandis, the positive image of Eve, "the good grandmother" is saved by transferring all the negative aspects to Lilith, "the wolf".
} 
The Apocrypha and Pseudepigrapha of the Old Testament, tr. R.H. Charles, Clarendon Press, 1913, vol. I-II, [online], http://www.ccel.org/ccel/charles/otpseudepig.i.html, http://www.pseudepigrapha.com.

The Soncino Midrash Rabbah, in: Judaic Classics Library (CD-ROM).

The Soncino Talmud, in: Judaic Classics Library (CD-ROM).

The Targums of Onkelos and Jonathan Ben Uzziel On the Pentateuch With The Fragments of the Jerusalem Targum From the Chaldee, tr. J. W. Etheridge, London 1862, [online], http://targum.info/targumic-texts/pentateuchal-targumim/.

\section{Secondary Literature}

Albright, William F., "The Goddess of Life and Wisdom”, The American Journal of Semitic Languages and Literatures, Vol. 36, No. 4 (1920), pp. 258-294.

Anthonioz, Stéphanie, "Water(s) of Abundance in the Ancient Near East and in Hebrew Bible Texts: A Sign of Kinship", in Thinking of Water in Judah, eds. Ehud Ben Zvi and Christoph Levin, (Berlin: de Gruyter, 2014), pp. 49-75.

Arbel, Vita Daphna, Forming Femininity in Antiquity: Eve, Gender, and Ideologies in the Greek Life of Adam and Eve, (New York: Oxford University Press, 2012).

Asplund Ingemark Camilla and Dominik Ingemark, "More than Scapegoating. The Therapeutic Potential of Stories of Child-Killing Demons in Ancient Greece and Rome", in Therapeutic Uses of Storytelling: An Interdisciplinary Approach to Narration as Therapy, ed. Camilla Asplund Ingemark, (Lund: Nordic Academic Press, 2014), pp. 75-84.

Bailey, John A., "Initiation and the Primal Woman in Gilgamesh and Genesis 2-3", Journal of Biblical Literature, Vol. 89, No. 2 (Jun., 1970), pp. 137-150.

Barbiero, Gianni, Song of Songs. A Close Reading, (Leiden: Brill, 2011).

Baring, Anne and Jules Cashford, The Myth of the Goddess: Evolution of an Image, (London: Penguin Books, 1991), pp. 514-546, http://www.womenpriests.org/body/baring4.asp, accessed July $20^{\text {th }}, 2016$.

Becking Bob, "Once in a Garden: Some Remarks on the Construction of the Identity of Woman and Man in Genesis 2-3", in Out of Paradise. Eve and Adam and Their Interpreters, Bob Becking and Susan Hennecke (eds.), (Sheffield: Phoenix Press, 2010), pp. 1-13.

Bercerra, Daniel, "El and the Birth of the Gracious Gods", Studia Antiqua, Vol. 6, No. 1/2008, pp. 51-56.

Bettelheim, Bruno, The Uses of Enchantment, Vintage Books 1976/2010 (e-book).

Black Koltuv, Barbara, The Book of Lilith, (Berwick Maine: Nicolas-Hays Inc., 1986). 
Blair, Judit, De-demonising the Old Testament. An Investigation of Azazel, Lilith, Deber, Qeteb and Reshef in the Hebrew Bible, [PhD thesis], (Edinburgh: University of Edinburgh, 2009).

Blau, Ludwig, “Amulet”, in Jewish Encyclopedia, ed. Isidore Singer et al., (New York: Funk \& Wagnalls Co., 1902), http://www.jewishencyclopedia.com, accessed November $15^{\text {th }}, 2015$.

Blenkinsopp, Joseph, “The Midianite-Kenite Hypothesis Revisited and the Origins of Judah", Journal for the Study of the Old Testament, 33.2 (2008), pp. 131-153.

Bloch-Smith, Elizabeth, "Acculturating Gender Roles: Goddess Images as Conveyors of Culture in Ancient Israel", in Izaak J. de Hulster, Joel M. LeMon (eds.), Image, Text, Exegesis. Iconographic Interpretation and the Hebrew Bible, (London et al.: Bloomsbury T\&T Clark: 2015), pp. 1-18.

Bunson, Matthew, The Vampire Encyclopedia, (New York: Gramercy Books, 1993).

Bokovoy, David E., "Did Eve Acquire, Create, or Procreate with Yahweh? A Grammatical and Contextual Reassessment of קנה in Genesis 4:1", Vetus Testamentum, No. 63 (2013), pp. $19-35$.

Burstein Amelia, Lilit - ha-Feministit ha-Rishonah. Keytzad Hishpi'u Re'ayonot Feministiim 'al ha-Qri'ah shel Sipur Lilit?, [term paper], http://goo.gl/PduaZu, accessed November $11^{\text {th }}$, 2015.

Carvalho, Diana, Woman Has Two Faces. Re-Examining Eve and Lilith in Jewish Feminist Thought, (Denver: University of Denver, 2009), [MA thesis].

Civil, Miguel, Ignace J. Gelb, A. Leo Oppenheim and Erica Reiner, The Assyrian Dictionary of the Oriental Institute of the University of Chicago, vol. 9, (Chicago: Oriental Institute, 1973).

Coblentz Bautch, Kelley, "What Becomes of the Angels' Wives? A Text-Critical Study of 1 Enoch 19:2," Journal of Biblical Literature, Vol. 125, No. 4 (2006), pp. 766-780.

Collins, C. John, "Adam and Eve in the Old Testament”, The Southern Baptist Journal of Theology, 15.1 (2011), pp. 4-25.

Dan, Joseph, "Samael, Lilith, and the Concept of Evil in Early Kabbalah”, AJS Review, Vol. 5 (1980), pp. 17-40.

DeConick, April D., Holy Misogyny: Why the Sex and Gender Conflicts in the Early Church Still Matter, (New York: Bloomsbury Publishing, 2011).

Dobroruka, Vicente, Second Temple Pseudepigraphy. A Cross-cultural Comparison of Apocalyptic Texts and Related Jewish Literature, (Berlin: Walter de Gruyter, 2014). 
Eshed, Eli, Sippurey Lilit, http://www.yekum.org/2013/03/סיפורי-לילית-אלי-אשד/, accessed: November $11^{\text {th }}, 2015$.

Even-Shoshan, Avraham, Ha-Milon He-Chadash, (Jerusalem: Kiryath Sepher, 1979).

Fernandes, Maria, "Lilith: From Powerful Goddess to Evil Queen”, in Revisitar o mito = Myths revisited, ed. Abel do Nascimento Pena, (Ribeirao: Húmus, 2015), pp. 727-737.

Folmer, Margaretha, "A Jewish Childbirth Amuletfor a Girl”, in Studies in Hebrew Literature and Jewish Culture. Presented to Albert van der Heide on the Occasion of his Sixty-Fifth Birthday, eds. Martin F.J. Baasten, Reinier Munk, (Dordrecht: Springer, 2007), pp. 41-57.

Gaster, Moses, “Two Thousand Years of a Charm against the Child-Stealing Witch”, Folklore. Transactions of the Folk-lore Society, Vol. XI, No. II, (1900), pp. 129-162.

Goldberg, Oskar, Rzeczywistość Hebrajczyków, tr. Tomasz Sikora, (Kraków: Nomos, 2012).

González Terriza, Alejandro A., Isis, Lilith, Gello: Three Ladies of Darkness, http://jewishchristianlit.com/Topics/Lilith/lilIsisGylu.html, accessed November 15 ${ }^{\text {th }}, 2015$.

Havrelock, Rachel, "The Myth of Birthing a Hero: Heroic Barrenness in the Hebrew Bible", Biblical Interpretation, 16/2007, pp. 154-178.

Hirsch, Emil G., Schechter, Solomon, and Ludwig Blau, "Lilith”, in Jewish Encyclopedia, ed. Isidore Singer et al., (New York: Funk \& Wagnalls Co., 1902), http://www.jewishencyclopedia.com, accessed November $15^{\text {th }}, 2015$.

Hutter, Manfred, "Lilith", in Dictionary of Deities and Demons in the Bible, eds. Karel van der Toorn, Bob Becking, Pieter Willem van der Horst, (Leiden-Boston-Koln: Brill, 1999), pp. 520-521.

Jastrow, Morris, “Adam and Eve in Babylonian Literature”, The American Journal of Semitic Languages and Literatures, Vol. 15, No. 4 (1899), pp. 193-214.

Joines, Karen Randolph, "The Bronze Serpent in the Israelite Cult", Journal of Biblical Literature, Vol. 87, No. 3 (1968), pp. 245-256.

Kadari, Tamar. "Eve: Midrash and Aggadah", in Jewish Women: A Comprehensive Historical Encyclopedia, http://jwa.org/encyclopedia/article/eve-midrash-and-aggadah, accessed November $15^{\text {th }}, 2015$.

Kikawada, Isaac M., “Two Notes on Eve”, Journal of Biblical Literature, Vol. 91, No. 1 (Mar., 1972), pp. 33-37.

Kosior, Wojciech, "The Angel in the Hebrew Bible from the Statistic and Hermeneutic Perspectives. Some Remarks on the Interpolation Theory", The Polish Journal of Biblical Research, Vol. 12, No. 23 (1/2013), pp. 55-70. 
Labovitz, Gail, “Is Rav's Wife «a Dish»? Food and Eating Metaphors in Rabbinic Discourse of Sexuality and Gender Relations", Studies in Jewish Civilization 18: Love-Ideal and Real -in the Jewish Tradition, eds. Leonard J. Greenspoon, Ronald A. Simkins, Jean A. Cahan, (Creighton University Press, 2008), pp. 147-170.

Lawee, Eric, "The Reception of Rashi's Commentary on the Torah in Spain: The Case of Adam's Mating with the Animals", The Jewish Quarterly Review, Vol. 97, No. 1 (2007), pp. $33-66$.

Lesses, Rebecca, "Exe(o)rcising Power: Women as Sorceresses, Exorcists, and Demonesses in Babylonian Jewish Society of Late Antiquity", Journal of the American Academy of Religion, Vol. 69, No. 2 (2001), pp. 343-375.

Lesses, Rebecca, "Lilith", in Encyclopedia of Religion, ed. Lindsay Jones et at., $2^{\text {nd }}$ edition, vol. 8, (Detroit et al.: Thomson Gale 2005), pp. 5458-5460.

Lohr, Joel N., "Sexual Desire? Eve, Genesis 3:16, and תשוקה", Journal of Biblical Literature, Vol. 130, No. 2 (2011), pp. 227-246.

Malul, Meir, "Terror of the night", in Dictionary of Deities and Demons in the Bible, eds. Karel van der Toorn, Bob Becking, Pieter Willem van der Horst, (Leiden-Boston-Koln: Brill, 1999), pp. 851-854.

Meier, Samuel A., "angel I", in Dictionary of Deities and Demons in the Bible, eds. Karel van der Toorn, Bob Becking, Pieter Willem van der Horst, (Leiden-Boston-Koln: Brill, 1999), pp. 45-50.

Meier, Samuel A., "angel of Yahweh", in Dictionary of Deities and Demons in the Bible, eds. Karel van der Toorn, Bob Becking, Pieter Willem van der Horst, (Leiden-Boston-Koln: Brill, 1999), pp. 53-59.

Montgomery, James A., Aramaic Incantation Texts from Nippur, (Philadelphia: University Museum, 1913).

Moore, Stuart J., Myth and Motif: Lilith in Jewish Tradition, [term paper], 2006, https://www.academia.edu/11975779/Myth_and_Motif_Lilith_in_Jewish_Tradition, accessed November $15^{\text {th }}, 2015$.

Orlov Andrei, Dark Mirrors: Azazel and Satanael in Early Jewish Demonology, (New York: SUNY Press, 2011).

Orlov Andrei, Divine Scapegoats: Demonic Mimesis in Early Jewish Mysticism, (Albany: SUNY Press, 2015). 
Orr, Gili, The medieval Alpha Beta deBen Sira I ("Rishona"): A parody on Rabbinic literature or a Midrashic commentary on ancient proverbs?, [PhD thesis], (Amsterdam: University of Amsterdam, 2009).

Ottenheijm Eric, “Eve and 'Women's Commandments' in Orthodox Judaism Perspective, in Out of Paradise. Eve and Adam and Their Interpreters, Bob Becking and Susan Hennecke (eds.), (Sheffield: Phoenix Press, 2010), pp. 157-173.

Parke-Taylor, Geoffrey H., Yahweh: The Divine Name in the Bible, (Ontario: Wilfrid Laurier University Press, 1975).

Patai, Raphael, The Hebrew Goddess, (Detroit: Wayne State University Press, 1990).

Penney, Douglas L. and Michael O. Wise, "By the Power of Beelzebub: An Aramaic Incantation Formula from Qumran (4Q560)", Journal of Biblical Literature, Vol. 113, No. 4 (1994), pp. 627-650.

Pereira, Filomena, Lilith: the edge of forever, [MA thesis], (San Jose: San Jose State University, 1995).

Pintel-Ginsberg, Idit, Lilit - Toldot ha-Musag u-Me'aphyeney Dmutah, [MA thesis], (Jerusalem: Hebrew University, 1981), http://hcc.haifa.ac.il/ deamon/lessons/12/lilit12.htm, accessed November $11^{\text {th }}, 2015$.

Poorthuis, Marcel J.H.M., "Who Is to Blame: Adam or Eve? A possible Jewish source for Ambrose's De paradiso 12,56", Vigiliae Christianae, Vol. 50, No. 2 (1996), pp. 125-135.

Puech, Emile, "Lel", in Dictionary of Deities and Demons in the Bible, eds. Karel van der Toorn, Bob Becking, Pieter Willem van der Horst, (Leiden-Boston-Koln: Brill, 1999), pp. 508-511.

Ra'anan, Moshe, Qa'at ve-Qippod (Mo'ed Qatan 25b), http://daf-yomi.com/DYItemDetails.aspx?itemId=28259, accessed November $11^{\text {th }}, 2015$.

Sandmel, Samuel, “Genesis 4:26b”, Hebrew Union College Annual, 22 (1961), pp. 19-29.

Schmutzer, Andrew J., "Psalm 91: Refuge, Protection and its Use in the New Testament", in The Psalms: Language for All Seasons of the Soul, eds. Andrew J. Schmutzer, David M. Howard Jr., (Chicago: Moody Publishers, 2013), pp. 85-110.

Scholem, Gershom, Kabbalah, (New York: Penguin Group, 1978).

Segal, Moses Z., "Ben Sira, Simeon ben Jesus", in Encyclopedia Judaica, $2^{\text {nd }}$ Edition, eds. Fred Skolnik, Michael Berenbaum, vol. 3, (Detroit: Thomson Gale, 2007), p. 376.

Shaked, Saul, "Form and Purpose in Aramaic Spells: Some Jewish Themes", in Officina Magica. Essays on the Practice of Magic in Antiquity, ed. S. Shaked, (Leiden-Boston: Brill, 2005), pp. 1-30. 
Shinan, Avigdor and Yair Zakovitch, From Gods to God. How the Bible Debunked, Suppressed, or Changed Ancient Myths and Legends, (Lincoln: Nebraska University Press, 2012).

Spoto, Stephanie Irene, The Figure of Lilith and the Feminine Demonic in Early Modern Literature, (Edinburgh: The University of Edinburgh, 2012).

Stamatopoulos, Panagiotis, A mistranslation or a liberal rendering in Ps. 91/90:6 (LXX)?, [paper draft, no date of publication], https://www.academia.edu/4167142/_English_A_mistranslation_or_a_liberal_rendering_in_P salm_91_90_6_LXX_, accessed July 19 $9^{\text {th }}, 2016$.

Stuckrad, Kocku von, Constructing Femininity-the Lilith Case, http://www.richarddagan.com/10.1.1.93.2673.pdf, accessed November $15^{\text {th }}, 2015$.

Tennant, Frederick Robert, The Sources of the Doctrines of the Fall and Original Sin, (Cambridge: Cambridge University Press, 1903).

Toorn, Karel van der, "Hebat", in Dictionary of Deities and Demons in the Bible, eds. Karel van der Toorn, Bob Becking, Pieter Willem van der Horst, (Leiden-Boston-Koln: Brill, 1999), pp. 391-392.

Trachtenberg, Joshua, Jewish Magic and Superstition: A Study in Folk Religion, (New York: Behrman's Jewish Book House, 1939), http://sacred-texts.com/jud/jms/index.htm, accessed November $15^{\text {th }}, 2015$.

Tsumura, David T., “A Biblical Theology of Water. Plenty, Flood and Drought in the Created Order", in Keeping God's Earth: The Global Environment in Biblical Perspective, eds. Noah J. Toly and Daniel I. Block, (Downers Grove, IL: IVP Academic, 2010), pp. 165-184.

Ullendorf, Edward, "The Bawdy Bible", Bulletin of the School of Oriental and African Studies, University of London, Vol. 42, No. 3/1979, pp. 425-456.

Wallace, Howard N., "Eve", in The Anchor Bible Dictionary, ed. David Noel Freedman, (New York: Doubleday, 1997), (CD-ROM).

Wifall, Walter, The Sea of Reeds as Sheol, "Zeitschrift für die alttestamentliche Wissenschaft", Vol. 92, No. 3 (1980), pp. 325-332.

Wyatt, Nicolas, “Cain’s wife”, Folklore, Vol. 97, No. 1 (1986), pp. 88-95.

Wyatt, Nicolas, "Eve", in Dictionary of Deities and Demons in the Bible, eds. Karel van der Toorn, Bob Becking, Pieter Willem van der Horst, (Leiden-Boston-Koln: Brill, 1999), pp. 316-317.

Zakovitch, Yair, "Nechashim, Miqdashim, Lechashim u-Nashim", in Migvan De'ot uHashqafot 'al ha-Nachash be-Pardes, ed. Dror Kerem, (Jerusalem: Ha-Minhal le-Chinukh 
Hityashvuti ve-'Aliyat ha-No'ar ba-Misrad ha-Chinukh ha-Tarbut ve-ha-Sifrut, 1998), http:// mikranet.cet.ac.il/pages/item.asp?item=16205, accessed November $15^{\text {th }}, 2015$. 